\title{
Growth and metal bioconcentration by conspecific freshwater macroalgae cultured in industrial waste water
}

The bioremediation of industrial waste water by macroalgae is a sustainable and renewable approach to the treatment of waste water produced by multiple industries. However, few studies have tested the bioremediation of complex multi-element waste streams from coalfired power stations by live algae. This study compares the ability of three species of green freshwater macroalgae from the genus Oedogonium, isolated from different geographic regions, to grow in waste water for the bioremediation of metals. The experiments used Ash Dam water from Tarong power station in Queensland, which is contaminated by multiple metals ( $\mathrm{Al}, \mathrm{Cd}, \mathrm{Ni}$ and $\mathrm{Zn}$ ) and metalloids (As and Se) in excess of Australian water quality guidelines. All species had consistent growth rates in Ash Dam water, despite significant differences in their growth rates in "clean" water. A species isolated from the Ash Dam water itself was not better suited to the bioremediation of that waste water. While there were differences in the temporal pattern of the bioconcentration of metals by the three species, over the course of the experiment, all three species bioconcentrated the same elements preferentially and to a similar extent. All species bioconcentrated metals $(\mathrm{Cu}, \mathrm{Mn}, \mathrm{Ni}, \mathrm{Cd}$ and $\mathrm{Zn}$ ) more rapidly than metalloids (As, Mo and Se). Therefore, bioremediation in situ will be most rapid and complete for metals. Overall, all three species of freshwater macroalgae had the ability to grow in waste water and bioconcentrate elements, with a consistent affinity for the key metals that are regulated by Australian and international water quality guidelines. Together, these characteristics make Oedogonium a clear target for scaled bioremediation programs across a range of geographic regions. 
$3{ }^{1}$ MACRO - the Centre for Macroalgal Resources and Biotechnology, and School of Marine and

4 Tropical Biology, James Cook University, Townsville, Queensland, Australia 4811

$5 \quad$ *Corresponding author:

$6 \quad$ Email: david.roberts1@jcu.edu.au

$7 \quad$ Phone: +61747813463

Fax: +617 47815511

8 Word count (abstract and text): 4200 


\section{Introduction}

10 The cultivation of algae in industrial effluent provides an effective form of bioremediation as

11 algae can bioconcentrate metals from waste water (Mehta and Gaur 2005; Troell et al. 2009;

12 Hubbe et al. 2011) while also capturing carbon and producing sustainable biomass (Roberts et

13 al. 2013). Integrated algal culture is particularly suited to coal-fired power stations as they are

14 significant sources of both metal-contaminated waste water and $\mathrm{CO}_{2}$ (Roberts et al. 2013).

15 Water and $\mathrm{CO}_{2}$ are two critical constraints to sustainable and cost effective aquatic biomass

16 production (McGinn et al. 2011; Slade and Bauen 2013). Therefore, integrating algal cultivation

17 with coal-fired power stations provides a path to biomass production with concomitant

18 bioremediation.

19 The success of the integrated aquaculture model relies on identifying species of algae that are

20 able to satisfy a number of criteria. Target species should preferably be robust to a range of

21 environmental conditions, competitively dominant, and widely distributed. Alternatively, robust

22 local strains are required to be isolated for region-specific applications and avoid the introduction

23 of non-endemic species. Green freshwater macroalgae are particularly strong candidates for

24 scaled bioremediation and biomass production as they satisfy these criteria (Lawton et al. 2013).

25 In addition, macroalgae require little specialised equipment to harvest and process, and are able

26 to bioconcentrate a wide range of metal ions from solution (Saunders et al. 2012; Roberts et al.

27 2013; Lawton et al. 2013). Previous experimental research has shown that species of the

28 freshwater genus of macroalgae, Oedogonium, can maintain high productivities in "clean" water

29 monocultures, readily outcompete co-occurring species under a variety of environmental

30 conditions, and are widely distributed throughout temperate, sub-tropical and tropical climates in

31 Australia (Lawton et al. 2014). Oedogonium is a genus of unbranched filamentous algae with a

32 worldwide distribution and grows attached to the substrate or as free-floating mats. The

33 widespread distribution of the genus, coupled with a filamentous growth form that is easy to

34 harvest, make species within the genus key candidates for scaled bioremediation and biomass

35 production.

36 The maintenance of high growth rates in biomass production is the cornerstone to developing

37 effective algal-based bioremediation (Roberts et al. 2013). There can be substantial variation in

38 growth rates between conspecific species of Oedogonium in small-scale laboratory cultures

39 (Lawton et al. 2014). However, it is unclear whether variation exists between conspecific species

40 in contaminated waste water and whether growth rates in clean water translates to similar

41 growth rates in waste water, and the bioconcentration of metals therein. The bioconcentration of

42 metal ions by macroalgae is a two phase process involving adsorption (rapid and passive 
43 sorption of metal ions to cellular surfaces) followed by absorption (metabolically facilitated

44 internalisation of metal ions) (Genter 1996; Volesky 2007). The rate of bioremediation of metals

45 from industrial waste waters therefore varies depending upon the growth rate of the species,

46 with high growth rates having the dual benefit of delivering more rapid bioremediation and more

47 biomass for end-use applications (Roberts et al. 2013). Macroalgae have an ability to tolerate

48 high metal concentrations in water through the production of metal-binding phytochelatins

49 (Pawlik-Skowrońska 2001) and polyphosphate bodies (Nishikawa et al. 2003), or the

50 sequestration of metals in storage vacuoles (Hanikenne et al. 2005). While these are ubiquitous

51 properties of marine and freshwater species alike, co-occurring conspecifics can have

52 significantly different metal profiles in situ (Brown et al. 1999; Sawidis et al. 2001; Roberts et al.

53 2008) demonstrating the potential for significant variations in the suitability of conspecific species

54 for bioremediation applications.

We have previously demonstrated that Oedogonium can be cultivated in industrial waste water from a coal-fired power station for the purposes of carbon capture and bioconcentration of a range of metals (Al, Cd, Ni and $\mathrm{Zn}$ ) and metalloids (As and Se for the purposes of this study) using a locally isolated species (Roberts et al. 2013). However, a key uncertainty is whether other clearly differentiated species within the genus Oedogonium from different geographic locations have a similar capacity to grow and bioconcentrate metals and metalloids from waste water to provide a bioremediation service. In this study we build upon previous experimental research by measuring the growth rates and bioremediation of metals from a real-world industrial effluent using multiple species of Oedogonium. We address two key questions. First, do species of Oedogonium have a consistent ability to grow in metal-contaminated waste water from a coal fired power station? Second, do species of Oedogonium bioconcentrate a similar quantity and composition of metals from complex waste water? Together, these data provide a basis to begin to assess the suitability of the genus Oedogonium more generally as a target for scaled bioremediation programs across broad geographic regions.

\section{Materials and Methods}

\section{Biomass and effluent collection}

Three species of filamentous algae from the genus Oedogonium were used in the cultivation experiments. One species was collected from the Ash Dam water (ADW) storage at Tarong power station in October 2012 ('Tarong Oedogonium'), while the other two species were collected from irrigation ditches in the Brandon sugarcane region. Attempts at species level 
75 identification of the three species were made using taxonomic keys (Yee and Entwisle 2011), however, the lack of clear morphological characteristics meant that the species could not be identified beyond genus level. The species were therefore assessed using molecular techniques, arguably the most effective approach to identifying cryptic species, and each was determined to be a unique genotype, supporting its assignment as a unique species (Lawton et al. 2014). As the three isolates could not be matched to extant species of Oedogonium on the basis of classical taxonomic features they are hereafter referred to by their GenBank accession numbers. The Tarong Oedogonium isolate $\left(26.76^{\circ} \mathrm{S}, 151.92^{\circ} \mathrm{E}\right.$; temperate) has the accession number

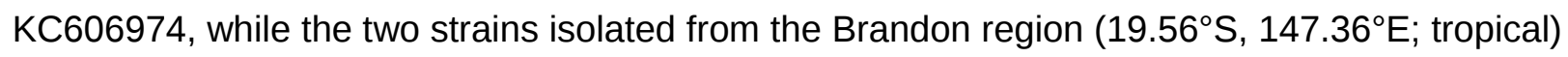
in far north Queensland, have the accession numbers KC701473 and KF606977. The strains from the Brandon region were first collected in 2010 and have been maintained in culture at James Cook University (JCU) for more than 2 years. All three species have been maintained in stock cultures at the Marine and Aquaculture Research Faculties Unit (MARFU), JCU, Douglas campus $\left(19.33^{\circ} \mathrm{S}, 146.76^{\circ} \mathrm{E}\right)$, in dechlorinated town water (DTW) with $\mathrm{f} / 2$ media addition since collection.

The ADW used in this study is an effluent created during ash disposal practices at a coal-fired power station. ADW was sourced directly from the Tarong coal-fired power station in south-east Queensland $\left(26.76^{\circ} \mathrm{S}, 151.92^{\circ} \mathrm{E}\right)$ and transported to James Cook University (JCU), Townsville in clean plastic 1000 L Intermediate Bulk Containers (IBCs) in November 2012. The ADW was then stored at ambient temperature in 12,000 L storage tanks. A sub-sample of this water was taken from the storage tank for this study in December 2012 and subject to elemental analysis to quantify initial conditions in the effluent (Table 1). The ADW was provided by Stanwell Energy Corporation.

\section{Experimental design}

A cultivation study was conducted to assess the growth of the three species of Oedogonium, as well as the bioconcentration of metals and metalloids from the ADW. The experiments were conducted within a climate controlled room $\left(28^{\circ} \mathrm{C}, 100 \mu \mathrm{mol}\right.$ photons $\mathrm{m}^{-2} \mathrm{~s}^{-1}$ and a 12 light: 12 dark photoperiod). The experimental temperature was chosen to reflect the median daytime temperature at the time of running the experiments. Stock cultures of each species were maintained for five weeks in DTW with $f / 2$ nutrient addition ( 0.1 g Aquasonic $₫ f / 2$ growth media $\left.\mathrm{L}^{-1}\right)$ to acclimate them to the experimental conditions. The aim of the acclimation period was to attain 'steady state' productivity, defined here as $<5 \%$ change in Specific Growth Rate (SGR) for two consecutive weeks prior to initiating the experiment. This was achieved on day 35 (Figure S1), and from this time point onwards the three species were cultivated in either Ash Dam water 
109 or DTW with $\mathrm{f} / 2$ addition as described below, for three consecutive growth periods of seven

110 days. The experimental period therefore spanned 21 days and consisted of three cultivation and

111 harvest cycles of equal duration as described below.

112 The three species of Oedogonium were cultured in $1 \mathrm{~L}$ Schott bottles at an initial stocking

113 density $0.5 \mathrm{~g}$ fresh weight $(\mathrm{FW}) \mathrm{L}^{-1}$. The FW was measured by gently blotting surface moisture

114 from the biomass and weighing it. The Schott bottles were stocked with biomass from one of the

115 three species and filled with either ADW or DTW amended with $\mathrm{f} / 2$ media, and then placed

116 randomly in the climate controlled room. The bottles were aerated with compressed air delivered

117 via a Pasteur pipette (at a flow rate of $0.2 \mathrm{~L} \mathrm{~min}^{-1}$ ) to each replicate bottle, and they were

118 randomly redistributed on a daily basis to avoid possible light bias in the experimental area.

119 Each replicate bottle was harvested every seven days by pouring the contents through $20 \mu \mathrm{m}$

120 filter mesh. A sample of the water was filtered $(0.45 \mu \mathrm{m})$ and retained for metal analysis. The

121 biomass was blot-dried with paper towel and weighed to the nearest $0.1 \mathrm{~g}$. A sub-sample of this

122 biomass was returned to the bottle with new water and growth media to reset the stocking

123 density at $0.5 \mathrm{~g} \mathrm{FW} \mathrm{L}^{-1}$. Any remaining biomass from each harvest was then dried in a

124 dehydrator for 48 hours at $60^{\circ} \mathrm{C}$.

125 Growth rates for each of the treatments were calculated based upon the FW determined for 126 eight consecutive growth periods of seven days ( $\mathrm{t}=$ Day 7$)$. The Specific Growth Rate, SGR (\% $127 \mathrm{FW} \mathrm{d}^{-1}$ ), was calculated using the equation:

$128 \quad \mathrm{SGR}=\operatorname{Ln}\left(\mathrm{W}_{f} / \mathrm{W}_{i}\right) / \mathrm{T} * 100$

129 Where $\mathrm{W}_{f}=$ the final weight $(\mathrm{g} \mathrm{FW})$ of biomass, $\mathrm{W}_{i}=$ the initial weight $(\mathrm{g} \mathrm{FW})$ of biomass, and $\mathrm{T}$ $130=$ the number of days in culture (7). 
131

\section{Elemental analysis}

132 The algal biomass and the two water sources (ADW and DTW) were each analysed for the 133 same 17 elements at the start of the experiment (Table 1). Water samples were collected using a $13460 \mathrm{~mL}$ syringe and filtered $(0.45 \mu \mathrm{m})$ to remove particulates. The concentrations of the 17 135 elements (Table 1) were also determined for all three species of Oedogonium grown in the Ash 136 Dam water treatments before exposure to Ash Dam water, and at each of the three time points 137 during the 21 day experimental period when Oedogonium was cultivated in Ash Dam water. All 138 biomass was prepared for the analysis by drying in a dehydrator for $48 \mathrm{~h}$ at $60^{\circ} \mathrm{C}$, then digesting 139100 milligrams $(\mathrm{mg})$ of the dried algae in a Teflon digestion vessel with 3.0 milliliters (ml) 140 double distilled $\mathrm{HNO}_{3}$ and $1.0 \mathrm{ml}$ analytical grade $\mathrm{H}_{2} \mathrm{O}_{2}$. The solution was digested for 2

$141 \mathrm{~h}$ then heated in a microwave oven to $180^{\circ} \mathrm{C}$ for $10 \mathrm{~min}$, then diluted with Milli-Q water. 142 The concentrations of $\mathrm{Al}, \mathrm{As}, \mathrm{Ba}, \mathrm{Cd}, \mathrm{Co}, \mathrm{Cr}, \mathrm{Cu}, \mathrm{Fe}, \mathrm{Mg}, \mathrm{Mn}, \mathrm{Mo}, \mathrm{Ni}, \mathrm{Pb}, \mathrm{Se}, \mathrm{Sr}, \mathrm{V}$ and $\mathrm{Zn}$ were 143 measured with a Bruker 820-MS Inductively Coupled Plasma Mass Spectrometer (ICP-MS). An 144 external calibration strategy was used for both instruments with a series of multi-element 145 standard solutions containing all of the elements of interest (three standard solutions were tested

\section{Statistical analysis}

154 As the aim of the experiment was to compare long-term growth rates for the three species of

155 Oedogonium in Ash Dam water with DTW, the mean growth rate was determined for each

156 replicate over the course of the three week experimental period containing the ADW treatments.

157 The mean growth rate was then analysed by two-factor analysis of variance (ANOVA) for the

158 main experimental factors of water source (Ash Dam water and DTW) and species. Where

159 necessary the growth data were log transformed (Quinn and Keough 2002). Residual

160 histograms and scatter plots of residuals vs. estimates were assessed to determine normality

161 and homogeneity of variance respectively (Quinn and Keough 2002). Post-hoc comparisons for 162 main effects and their interactions were made using Tukey's HSD multiple comparisons. 
163 The concentrations of metals in the algal biomass were first subject to multivariate ordination

164 with non-metric Multi-dimensional Scaling (nMDS) to assess multivariate patterns in the

165 temporal profile of metal bioconcentration from Ash Dam water by the three species. The mean

166 data for the metal concentration within the biomass $\left(\mathrm{mg} \mathrm{kg}^{-1}\right)$ were reassembled in a Bray-Curtis

167 similarity matrix, focusing specifically on elements for which there are existing Australian and

168 New Zealand Environmental Control Council (ANZECC) water quality criteria (see Table 1 for

169 ANZECC water quality criteria). Mean metal contents of the three species were then contrasted

170 for individual metals with a one-way ANOVA with the factor 'species'. The elemental

171 concentration of the algal biomass was also converted to a bioconcentration factor (BCF) for

172 elements that have stipulated ANZECC trigger values. The BCF is the ratio of the element

173 concentration in the water, to the final concentration in the biomass (DeForest et al. 2007). The

174 bioconcentration factor (BCF) was calculated using the equation:

$175 \quad \mathrm{BCF}=\mathrm{C}_{b} / \mathrm{C}_{w}$

176 Where, $C_{b}$ is the concentration of the element in the dry macroalgal biomass $\left(\mathrm{mg} \mathrm{kg}^{-1}\right)$ and $\mathrm{C}_{w}$ is

177 the initial concentration of the element in the water phase $\left(\mathrm{mg} \mathrm{L}^{-1}\right)$. The BCF is therefore a

178 dimensionless ratio that expresses uptake of elements relative to availability in the water

179 sample.

180

Results

181

Elemental profile of Ash Dam water and DTW

182 The elemental composition of the Ash Dam water was complex with several metals and

183 metalloids at concentrations significantly higher than the relevant ANZECC water quality criteria

184 (Table 1). The concentrations of $\mathrm{Al}, \mathrm{As}, \mathrm{Cd}, \mathrm{Mg}, \mathrm{Mn}, \mathrm{Mo}, \mathrm{Ni}, \mathrm{Se}, \mathrm{Sr}, \mathrm{V}$ and $\mathrm{Zn}$ were all

185 significantly higher in Ash Dam water than DTW (two-tailed $t$ test, $\mathrm{P}<0.05$ ), with the

186 concentration of $\mathrm{Al}, \mathrm{As}, \mathrm{Cd}, \mathrm{Ni}$, Se and $\mathrm{Zn}$ exceeding the ANZECC trigger values designated for

187 the protection of aquatic life at the 95\% level (Table 1). The Ash Dam water is therefore a

188 complex industrial effluent with multiple metal (Al, Cd, Ni and $\mathrm{Zn}$ ) and metalloid (As and Se)

189 targets for bioremediation. The remainder of the results section will focus on those elements that

190 exceed ANZECC water quality criteria as the aim of the study is to ascertain interspecific

191 variation in the potential for bioremediation. 
193 'Steady state' productivity (defined here as < 5\% change in SGR for two consecutive weeks)

194

195

196

197

198

199

200

201

202

203

204

205

206

207

208

209

210

211

212

213

214

215

216

217

218

219

220

221

222

223 was attained after 5 weeks of acclimation for all three species (Figure S1). Acclimation to 'steady state' productivity was conducted to minimise any anomalous growth rates during the experiments as a result of changing photo-regime ( $\mu \mathrm{mol}$ photons $\left.\mathrm{m}^{-2} \mathrm{~s}^{-1}\right)$ and photoperiod associated with the biomass being sourced from stock cultures and subsequently exposed to controlled experimental conditions. During this period, one of the Oedogonium species (KC701473) had a significantly higher mean productivity (23\% SGR) than the other two species ( 20\% SGR for both KF606977 and KC606974; Figure S1).

After acclimation, all three species were exposed to either Ash Dam water or DTW with nutrient addition. There was a significant 'species $\mathrm{x}$ water source' interaction for the mean growth rates of the three species of Oedogonium ("Species x Water Source": $F_{2,12}=4.95, P=0.027$ ). The growth rate of one species of Oedogonium (KC701473) was significantly higher than the growth rates of the two other species in DTW (Figure 1). KC701473 had a mean SGR of 26\% in DTW, in comparison to the other species that had a mean SGR of 20\% (KF606977) and 16\% (KC606974) over the three week experimental period (Figure 1).

The overall growth rates for each species were reduced in Ash Dam water relative to those in DTW, with the greatest reduction for KC701473 (decreasing from 26\% in DTW to $7.5 \%$ in Ash Dam water) (Figure 1). However, in contrast to the significant difference observed in growth between the three species when grown in DTW, there was no difference in the growth rates between the three species of Oedogonium in Ash Dam water (Figure 1). There was an apparent trend towards higher SGR for the Oedogonium from the Brandon region (KF606977) and Tarong (KC606974) than KC701473 in Ash Dam water (Figure 1), but these differences were not statistically significant (Figure 1).

\section{Patterns in metal and metalloid bioconcentration}

All three species had low concentrations of most elements at the end of the acclimation period in DTW, although KC701473 had a significantly higher K content than the other two Oedogonium species (Supplementary Materials Table S1). There were no significant differences between the three species of Oedogonium with respect to mean bioconcentration of metals or metalloids over the course of the experiment (Figure 2). The only elements for which there was a significant difference in bioconcentration between species of Oedogonium were $\mathrm{Cd}$ and As. Cd was bioconcentrated to a significantly higher concentration in KF606977 and KC606974 than 
224

225

226

227

228

229

230

231

232

233

234

235

236

237

238

239

240

241

242

243

244

245

246

247

248

249

250

251

252

253

254

255

KC701743 (Figure 3b, Table 2), while As was bioconcentrated to a significantly higher concentration in KC701743 than the other two species (Figure 3e, Table 2). The remaining elements showed no significant differences in their bioconcentration between the three species of Oedogonium. (Figure 3, Table 2). The majority of elements that did not initially exceed ANZECC criteria also had similar concentrations in the three species of Oedogonium at the conclusion of the experiment (Supplementary Materials Figure S2 and Table S2).

While the mean bioconcentration of metals and metalloids did not differ between the three species by the end of the experiment, there were minor differences in the temporal pattern of metal bioconcentration. The clustering of the three species with respect to the vector orientation in the MDS supports a temporal sequence in metal uptake and that this differs between the three species. In the first week following the transfer of the cultures to Ash Dam water, all three species bioconcentrated a subset of elements from Ash Dam water ( $\mathrm{Mn}, \mathrm{Pb}$ and Fe, Figure 4), however, KC606974 and KF606977 bioconcentrated the metals Cd, Ni and Zn much more rapidly in the first week than KC701473 (Figure 4). By week two, KC701473 had a similar element profile to the other species having bioconcentrated the trace elements $\mathrm{Al}, \mathrm{Cd}, \mathrm{Ni}, \mathrm{Se}$ and $\mathrm{Zn}$, while KC606974 clustered with the group of element vectors of $\mathrm{Se}, \mathrm{Ni}, \mathrm{Zn}, \mathrm{Cd}, \mathrm{Al}$ and $\mathrm{B}$ and had the highest internal concentrations of these elements in week 2 (Figure 4). In the third week of cultivation, the elemental profile of the Oedogonium KC606974 was similar to its initial (post-acclimation) composition, while the other two Oedogonium species (KC701473 and KC606974) continued to have higher concentrations of elements (Figure 4).

These patterns are also clearly reflected in the temporal sequence of bioconcentration of metals (Al, Cd, Ni and Zn) and metalloids (As, Se) that exceeded ANZECC criteria by the three species of Oedogonium. The four metals (Al, $\mathrm{Cd}, \mathrm{Ni}$ and $\mathrm{Zn}$ ) were bioconcentrated more rapidly by Oedogonium isolate KC606974 and KF606977 than KC701473. There were significantly higher internal concentrations of $\mathrm{Al}, \mathrm{Cd}, \mathrm{Ni}$ and $\mathrm{Zn}$ in these two species after one week of exposure to Ash Dam water (Figure 5a-d). However, the internal concentrations of $\mathrm{Al}, \mathrm{Cd}$ and $\mathrm{Ni}$ in the three species converged and were not different by the end of the experiment, while $\mathrm{Zn}$ remained higher in KF606977 than the other two species (Figure 5d). In contrast, bioconcentration of As differed between the three species, with significantly higher As contents in KC701473 than KF606977 and KC606974 by the end of the experiment (Figure 5e). There were no significant differences in the rate or extent of bioconcentration of Se by the three Oedogonium species (Figure 5f). 
257 The element bioconcentration factors were very consistent between the three species of

258 Oedogonium. For all species, the highest BCF was attained for $\mathrm{Cu}, \mathrm{Mn}, \mathrm{Zn}$ and Ni with values

259 ranging from 709-1418 for $\mathrm{Zn}, 889-1256$ for $\mathrm{Ni}, 6938-8943$ for $\mathrm{Cu}$, and 5892-16719 for $\mathrm{Mn}$

260 (Tables 4 and 5). Conversely, Al, Se and Mo all had the lowest BCF with values of 3-4 for Mo,

261 79-93 for Se and 259-351 for Al (Tables 4 and 5). The ranking of the BCF amongst elements

262 was, however, relatively consistent with the same four elements ( $\mathrm{Cu}, \mathrm{Mn}, \mathrm{Zn}$ and $\mathrm{Ni})$ having the

263 highest BCF for all three species, while the same three elements (AI, Se and Mo) had the lowest

264 BCF for all species (Table 4).

\section{Discussion}

266 To be a suitable candidate for bioremediation applications, a target group of macroalgae should 267 be widely distributed, robust to variable environmental conditions, be able to out-compete other

268 species in intensive culture, and grow at high rates. The genus Oedogonium is already known to 269 meet these criteria from individual studies investigating species within the genus (Lawton et al.

270 2013). However, it remains unresolved as to whether individual species within the genus also

271 have a similar capacity to grow and bioconcentrate metals and metalloids from waste water to

272 provide a bioremediation service - given that there is substantial conspecific variation in growth

273 rates and in metal concentrations for macroalgae more generally (Lawton et al. 2014). Our

274 results clearly demonstrate that the individual species within the genus Oedogonium that were

275 assessed in this study have an equal capacity to grow in a complex industrial waste stream, and

276 to sequester metals and metalloids from this waste stream to provide a bioremediation service.

277 The specific growth rates (SGR) of Oedogonium averaged approximately $12 \% \mathrm{~d}^{-1}$ in complex 278 waste water containing multiple elements that require remediation. Interestingly, all three species 279 of Oedogonium had a similar SGR in Ash Dam water, despite quite significant differences in 280 SGR when the same species were cultivated in DTW. These differences were evident during 281 both the acclimation and experimental cultivation periods in DTW. The consistently lower growth 282 rates of Oedogonium in Ash Dam water demonstrate that the growth rates of individual species 283 in clean-water cultures cannot be used to predict their productivities in metal-contaminated 284 waste waters, for which there was a relatively consistent reduction in SGR of approximately $28550 \%$. Furthermore, the species-level traits that confer more rapid growth rates in DTW do not 286 confer more rapid growth rates in industrial effluent. The SGR of all species was higher in DTW, 287 and for this reason site-specific evaluations of potential growth rates in industrial effluents will be 288 required. In general, our data support the prediction that the species of the genus Oedogonium 289 are strong candidates for metal-bioremediation programs given their ability to deliver consistent 
growth in complex effluents while accumulating metals and metalloids over time. However, this conclusion needs to be tempered in that individual species will always require trials to ensure

292 their efficacy in complex waste streams, in ambient environmental conditions, and that the

293 bioremediation of waste streams will, by nature of the composition of the waste stream and the 294 endemic flora, be influenced by site-specific water quality profiles.

295 In addition to having similar growth rates, the three species of Oedogonium also had very similar 296 patterns of metal bioconcentration. While there were minor differences in the temporal pattern of 297 the bioconcentration of some elements between the three species, the mean bioconcentration of 298 ANZECC-listed elements over the course of the experiments did not differ for the majority of 299 elements. Each of the species was able to bioconcentrate internal metal and metalloid 300 concentrations orders of magnitude above their concentrations in the Ash Dam water. The three 301 species also had very similar elemental composition over the course of the experiment, and 302 delivered consistent element-specific bioconcentration factors (BCFs) for each of the ANZECC303 listed elements. The metals $\mathrm{Cu}, \mathrm{Mn}, \mathrm{Zn}$ and Ni were bioconcentrated to a significantly higher 304 degree by the species of Oedogonium than the metalloids Mo and Se, supporting what has 305 previously been published for single species (Saunders et al. 2012; Roberts et al. 2013). This 306 evidence adds to a clear consistency amongst studies that live algal cultures are effective at 307 sequestering metal cations, but are less effective at sequestering metalloids that occur as 308 oxyanions, particularly $\mathrm{Se}\left(\right.$ as $\mathrm{SeO}_{4}{ }^{2-}$ ), As (as $\mathrm{AsO}_{4}{ }^{3-}$ ) and $\mathrm{Mo}$ (as $\mathrm{MO}_{4}{ }^{2-}$ ) (Roberts et al. 2013). 309 The algal cell wall has a natural affinity for dissolved cations and this is exploited in the use of 310 dried biomass as a biosorbent for dissolved metals (Kidgell et al. in press). In contrast, dissolved 311 metalloids do not show a natural affinity for algal cell walls which may explain the limited uptake 312 in these experiments. Additionally, there may be significant competition for uptake sites in the 313 complex effluent tested in these experiments and the bioconcentration of the metalloids may be 314 expected to increase in the absence of competing ions.

315 The only significant differences between species of Oedogonium with respect to the 316 bioconcentration of elements were for the ANZECC metalloid As and the ANZECC metal Cd.

317 KC701473 had a significantly higher content of As than the other two species, but a lower

318 content of $\mathrm{Cd}$. There is some evidence that the presence of As in contaminated soils can reduce 319 the bioconcentration of Cd by terrestrial plants (Sun et al. 2009). Reduced Cd bioconcentration 320 in the presence of As could be a result of competition for common binding sites on the algal cell 321 wall by the two elements. Indeed, similar antagonistic relationships have been documented in 322 marine seaweeds where the presence of $\mathrm{Cu}$ can impede $\mathrm{Cd}$ bioconcentration (Roberts et al. 323 2008). The variance between the three species of Oedogonium with respect to As 
324

325

326

327

328

329

330

331

332

333

334

335

336

337

338

339

340

341

342

343

344

345

346

347

348

349

350

351

352

\section{Acknowledgements}

354 We thank Stanwell Energy Corporation for providing effluents for the experimental studies and Yi

$355 \mathrm{Hu}$ (Advanced Analytical Centre, James Cook University) for assistance with chemical analyses.

bioconcentration suggests it may be possible to identify species that are more effective at accumulating this metalloid, but there may be a trade-off of reduced $\mathrm{Cd}$ bioconcentration. There was also a slight difference in the temporal profile of metal bioconcentration, with the Tarong isolate KC606974 having rapid initial bioconcentration of the metals $\mathrm{Al}, \mathrm{Cd}, \mathrm{Ni}$ and $\mathrm{Zn}$, followed by a slower rate of bioconcentration in the later stages of the experiment. This could be indicative of an efficient metal detoxification pathway in this isolate that was originally collected from Tarong Ash Dam. Green freshwater macroalgae can develop efficient metal detoxification mechanisms such as the production of metal-binding phytochelatins to sequester and detoxify contaminants in cellular vacuoles, and this property is most pronounced in isolates that have been exposed to contaminants for a long period of time (Pawlik-Skowrońska 2001; PawlikSkowrońska 2003). Regardless, all species had low BCFs for metalloids, and bioconcentrated them at a slow rate relative to their availability in the effluent, and this finding is consistent with previous research that has highlighted the relatively slow rates of metalloid bioconcentration by green macroalgae relative to the rates at which metals are bioconcentrated (Roberts et al. 2013). Therefore, the three species of Oedogonium delivered equal growth rates and bioconcentrated the same elements preferentially such that the over-arching bioremediation potential of the three species was effectively the same. The genus Oedogonium therefore has a consistent ability to sequester a range of metals and metalloids from complex effluents for broad-spectrum remediation applications and, furthermore, it is possible to predict the key metals that will be most effectively remediated by conspecific species.

Importantly, we have demonstrated that species within the cosmopolitan algal genus Oedogonium have a consistent ability to bioconcentrate metals from waste water. One could therefore isolate native Oedogonium, potentially from the waste water source requiring remediation as we have done, and use these species to remediate waste water in intensive onsite cultivation. Notably, the Oedogonium KC606974 from Tarong used during this study is endemic at the Tarong power station (Stanwell Energy) and this provides an example of the capacity to use a native species for culture within the industrial waste stream (Ash Dam water from Tarong) to deliver the first step in a potentially larger integrated waste management process. 
356

357

358

359

360

361

362

363

364

365

366

367

368

369

370

371

372

373

374

375

376

377

378

379

380

381

382

383

384

385

386

387

388

389

390

391

392

393

394

395

396

397

398

399

400

401

402

403

404

405

406

\section{References}

Brown M, Hodgkinson W, Hurd C (1999). Spatial and temporal variations in the copper and zinc concentrations of two green seaweeds from Otago Harbour, New Zealand. Marine Environmental Research, 47:175-184.

DeForest DK, Brix KV, Adams WJ (2007). Assessing metal bioaccumulation in aquatic environments: the inverse relationship between bioaccumulation factors, trophic transfer factors and exposure concentration. Aquatic Toxicology, 84:236-246.

Genter RB (1996). Ecotoxicology of inorganic chemical stress to algae. In: Stevenson RJ, Bothwell ML, Lowe RL, ed. Algal ecology: freshwater benthic ecosystems. Amsterdam: Elsevier, 403-468.

Hanikenne M, Krämer U, Demoulin V, Baurain D (2005). A comparative inventory of metal transporters in the green alga Chlamydomonas reinhardtii and the red alga Cyanidioschizon merolae. Plant Physiolgy, 137:428-46.

Hubbe MA, Hasan SH, Ducoste JJ (2011). Cellulosic substrates for removal of pollutants from aqueous systems: a review. 1. Metals. Bioresources, 6:2161-2287.

Kidgell JT, de Nys R, Hu Y, Paul NA, Roberts DA (in press). Bioremediation of a complex industrial effluent by biosorbents derived from freshwater macroalgae. PLoS One. Accepted19.03.2014.

Lawton RJ, de Nys R, Paul NA (2013) Selecting reliable and robust freshwater macroalgae for biomass applications. PLoS One, 8:e64168.

Lawton RJ, de Nys R, Skinner S, Paul NA (2014) Isolation and selection of Oedogonium species and strains for biomass applications. PLoS One, 9:e90223.

McGinn PJ, Dickinson KE, Bhatti S, Frigon JC, Guiot SR, O'Leary SJB. (2011) Integration of microalgae cultivation with industrial waste remediation for biofuel and bioenergy production: opportunities and limitations. Photosynthetic Research, 109:231-247.

Mehta SK, Gaur JP (2005). Use of algae for removing heavy metal ions from wastewater: Progress and prospects. Critical Reviews in Biotechnology, 25:113-152.

Nishikawa K, Yamakoshi Y, Uemura I, Tominaga N (2003). Ultrastructural changes in Chlamydomonas acidophila (Chlorophyta) induced by heavy metals and polyphosphate metabolism. FEMS Microbiology Ecology, 44:253-9.

Pawlik-Skowrońska B (2001). Phytochelatin production in freshwater algae Stigeoclonium in response to heavy metals contained in mining water; effects of some environmental factors. Aquatic Toxicology, 52:241-249.

Pawlik-Skowrońska B (2003). Resistance, accumulation and allocation of zinc in two ecotypes of the green alga Stigeoclonium tenue Kütz. coming from habitats of different heavy metal concentrations. Aquatic Botany, 75:189-198.

Quinn GP, Keough MJ (2002). Experimental design and data analysis for biologists. Cambridge: Cambridge University Press.

Roberts DA, Johnston EL, Poore AGB (2008). Biomonitors and the assessment of ecological impacts: distribution of herbivorous epifauna in contaminated macroalgal beds. Environmental Pollution, 156:489-503.

Roberts DA, de Nys R, Paul NA (2013). The effect of $\mathrm{CO}_{2}$ on algal growth in industrial waste water for bioenergy and bioremediation applications. PLoS One, 8:e81631.

Saunders RJ, Paul NA, Hu Y, de Nys R (2012). Sustainable sources of biomass for bioremediation of heavy metals in waste water derived from coal-fired power generation. PLoS One, 7:e36470.

Sawidis T, Brown M, Zachariadis G, Sratis I (2001). Trace metal concentrations in marine macroalgae from different biotopes in the Aegean Sea. Environment International, 27:4347.

Slade R, Bauen A (2013). Micro-algae cultivation for biofuels: Cost, energy balance, environmental impacts and future prospects. Biomass and Bioenergy, 53:29-38.

PeerJ reviewing PDF | (v2014:03:1655:1:1:NEW 7 May 2014) 
407 Sun Y, Zhou Q, Liu W, An J, Xu Z, Wang L (2009). Joint effects of arsenic and cadmium on plant 408 growth and metal bioaccumulation: a potential Cd-hyperaccumulator and As-excluder 409 Bidens pilosa L. Journal of Hazard Materials, 165:1023-1028.

410 Troell M, Joyce A, Chopin T, Neori A, Buschmann AH, Fang JG (2009). Ecological engineering in 411 aquaculture - potential for integrated multi-trophic aquaculture (IMTA) in marine offshore 412 systems. Aquaculture, 297:1-9.

413 Volesky B (2007). Biosorption and me. Water Research, 41:4017-29.

414 Yee N, Entwisle TJ (2011). ALGAKEY- Interactive identification of Australian freshwater algae, 415 version 1. 


\section{Table 1 (on next page)}

Table 1

Elemental composition of dechlorinated town water and Ash Dam water. 


\begin{tabular}{|c|c|c|c|}
\hline Element & $\begin{array}{l}\text { Dechlorinated town water } \\
\left(\mu \mathrm{g} \mathrm{L}^{-1} \pm \mathrm{SE}\right)\end{array}$ & $\begin{array}{l}\text { Ash dam water } \\
\left(\mu \mathrm{g} \mathrm{L}^{-1} \pm \mathrm{SE}\right)\end{array}$ & $\begin{array}{c}\text { 95A\% ANZECC trigger } \\
\text { value } \\
\left(\mu \mathrm{g} \mathrm{L}^{-1}\right)\end{array}$ \\
\hline Aluminium & $10 \pm 5.8$ & $123.3 \pm 13.3^{a}$ & 55 \\
\hline Arsenic & $1 \pm 0.6$ & $33.7 \pm 1.2^{a}$ & 24 \\
\hline Barium & $<$ LOD & $<$ LOD & ID \\
\hline Cadmium & $0.1 \pm 0.1$ & $2.5 \pm 0.0^{a}$ & 0.2 \\
\hline Chromium & $<$ LOD & $<$ LOD & 1.0 \\
\hline Cobalt & $<$ LOD & $<$ LOD & ID \\
\hline Copper & $2 \pm 1.2$ & $1 \pm 0.0$ & 1.4 \\
\hline Iron & $50 \pm 58.9$ & $50 \pm 0.0$ & ID \\
\hline Lead & $1 \pm 0.6$ & $1 \pm 0.0$ & 3.4 \\
\hline Magnesium & $2 \pm 1.2$ & $92.7 \pm 0.7^{a}$ & ID \\
\hline Manganese & $1 \pm 0.6$ & $4 \pm 0.0^{a}$ & 1900 \\
\hline Molybdenum & $1 \pm 0.6$ & $1280 \pm 35.1^{a}$ & ID \\
\hline Nickel & $1 \pm 0.6$ & $34.7 \pm 0.3^{a}$ & 11 \\
\hline Selenium & $10 \pm 5.8$ & $70 \pm 0.0^{a}$ & 11 \\
\hline Strontium & $56.7 \pm 32.7$ & $2243 \pm 63.3^{a}$ & ID \\
\hline Vanadium & $10 \pm 5.8$ & $843.3 \pm 17.6^{a}$ & ID \\
\hline Zinc & $8 \pm 4.6$ & $55 \pm 0.6^{a}$ & 8.0 \\
\hline
\end{tabular}

${ }^{a}$ Significantly greater than dechlorinated town water (two-tailed t-test, $\mathrm{P}<0.05$ )

$<$ LOD - less than Level of Detection ( $1 \mu \mathrm{g} \mathrm{L}^{-1}$ for most elements)

ID = insufficient data to calculate ANZECC $95 \%$ trigger values

All data are mean concentrations \pm S.E.

Bold values exceed the ANZECC trigger value. 


\section{Table 2 (on next page)}

Table 2

Analysis of variance for ANZECC metals (Al, Cd, Ni and Zn) and metalloids (As and Se) concentrations in the three Oedogonium species after cultivation in ADW. 


\begin{tabular}{|c|c|c|c|c|c|c|c|c|c|c|c|c|c|c|c|c|c|c|}
\hline \multirow{2}{*}{ Factor } & \multirow{2}{*}{ df } & \multicolumn{2}{|c|}{ Aluminium } & \multicolumn{3}{|c|}{ Cadmium } & \multicolumn{3}{|c|}{ Nickel } & \multicolumn{3}{|c|}{ Zinc } & \multicolumn{3}{|c|}{ Arsenic } & \multicolumn{3}{|c|}{ Selenium } \\
\hline & & $\mathbf{M S} \stackrel{ }{\frac{2}{4}} \mathbf{F}$ & $\mathbf{P}$ & MS & $\mathbf{F}$ & $\mathbf{P}$ & MS & $\mathbf{F}$ & $\mathbf{P}$ & MS & $\mathbf{F}$ & $\mathbf{P}$ & MS & $\mathbf{F}$ & $\mathbf{P}$ & MS & $\mathbf{F}$ & $\mathbf{P}$ \\
\hline Species & 2 & $271.8 \stackrel{\frac{\omega}{D}}{\stackrel{\frac{\omega}{\sigma}}{c}} 0.73$ & 0.52 & 1.14 & 5.82 & 0.04 & 156.9 & 0.77 & 0.50 & 1141.6 & 3.66 & 0.09 & 178.1 & 7.41 & 0.02 & 10.1 & 0.67 & 0.55 \\
\hline Residual & 6 & $372.8^{\geq}$ & & 0.20 & & & 203.4 & & & 312.7 & & & 24.0 & & & 14.9 & & \\
\hline
\end{tabular}

Bold values are statistically sighificant $(P<0.05)$.

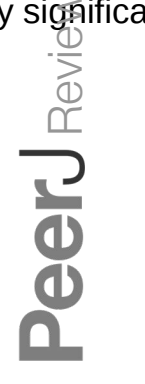




\section{Table 3 (on next page)}

Table 3

Bioconcentration factors for ANZECC-listed elements in Ash Dam water. 


\begin{tabular}{|c|c|c|c|c|c|}
\hline \multirow{2}{*}{ Element } & \multicolumn{2}{|l|}{$\begin{array}{c}\text { Ash dam } \\
\text { water }\left(\mathrm{mg} \mathrm{L}^{-1}\right)\end{array}$} & \multicolumn{2}{|c|}{ Bioconcentration factor } & \multirow[b]{2}{*}{ KC60697 } \\
\hline & $\frac{\text { 은 }}{\mathrm{D}}$ & & KF606977 & KC701473 & \\
\hline $\mathrm{Al}$ & 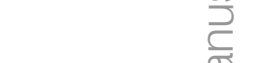 & 0.1233 & 276 & 259 & 351 \\
\hline As & $\sum^{\sigma}$ & 0.0337 & 481 & 504 & 721 \\
\hline $\mathrm{Cd}$ & O & 0.0025 & 730 & 288 & 642 \\
\hline $\mathrm{Cu}$ & $\cdot \frac{\varsigma}{3}$ & 0.001 & 6938 & 8943 & 8884 \\
\hline $\mathrm{Pb}$ & $\frac{d}{2}$ & 0.001 & 346 & 438 & 1009 \\
\hline $\mathrm{Mn}$ & $\underset{d}{d}$ & 0.004 & 5892 & 16719 & 12739 \\
\hline Mo & 5 & 1.28 & 3 & 3 & 3 \\
\hline $\mathrm{Ni}$ & 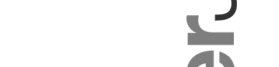 & 0.0347 & 889 & 929 & 1256 \\
\hline $\mathrm{Se}$ & () & 0.07 & 83 & 79 & 93 \\
\hline $\mathrm{Zn}$ & (d) & 0.055 & 1418 & 709 & 1033 \\
\hline
\end{tabular}




\section{Table 4 (on next page)}

Table 4

Bioconcentration factors in order of decreasing magnitude. 
KF606977

KC701473

KC606974
$\mathrm{Cu}>\mathrm{Mn}>\mathrm{Zn}>\mathrm{Ni}>\mathrm{Cd}>\mathrm{As}>\mathrm{Pb}>\mathrm{Al}>\mathrm{Se}>\mathrm{Mo}$

$\mathrm{Mn}>\mathrm{Cu}>\mathrm{Ni}>\mathrm{Zn}>\mathrm{As}>\mathrm{Pb}>\mathrm{Cd}>\mathrm{Al}>\mathrm{Se}>\mathrm{Mo}$

$\mathrm{Mn}>\mathrm{Cu}>\mathrm{Ni}>\mathrm{Zn}>\mathrm{Pb}>\mathrm{As}>\mathrm{Cd}>\mathrm{Al}>\mathrm{Se}>\mathrm{Mo}$ 


\section{Figure 1}

Figure 1

Specific Growth Rate of the three Oedogonium species in Ash Dam Water and Dechlorinated Town Water. Data are means \pm SE.

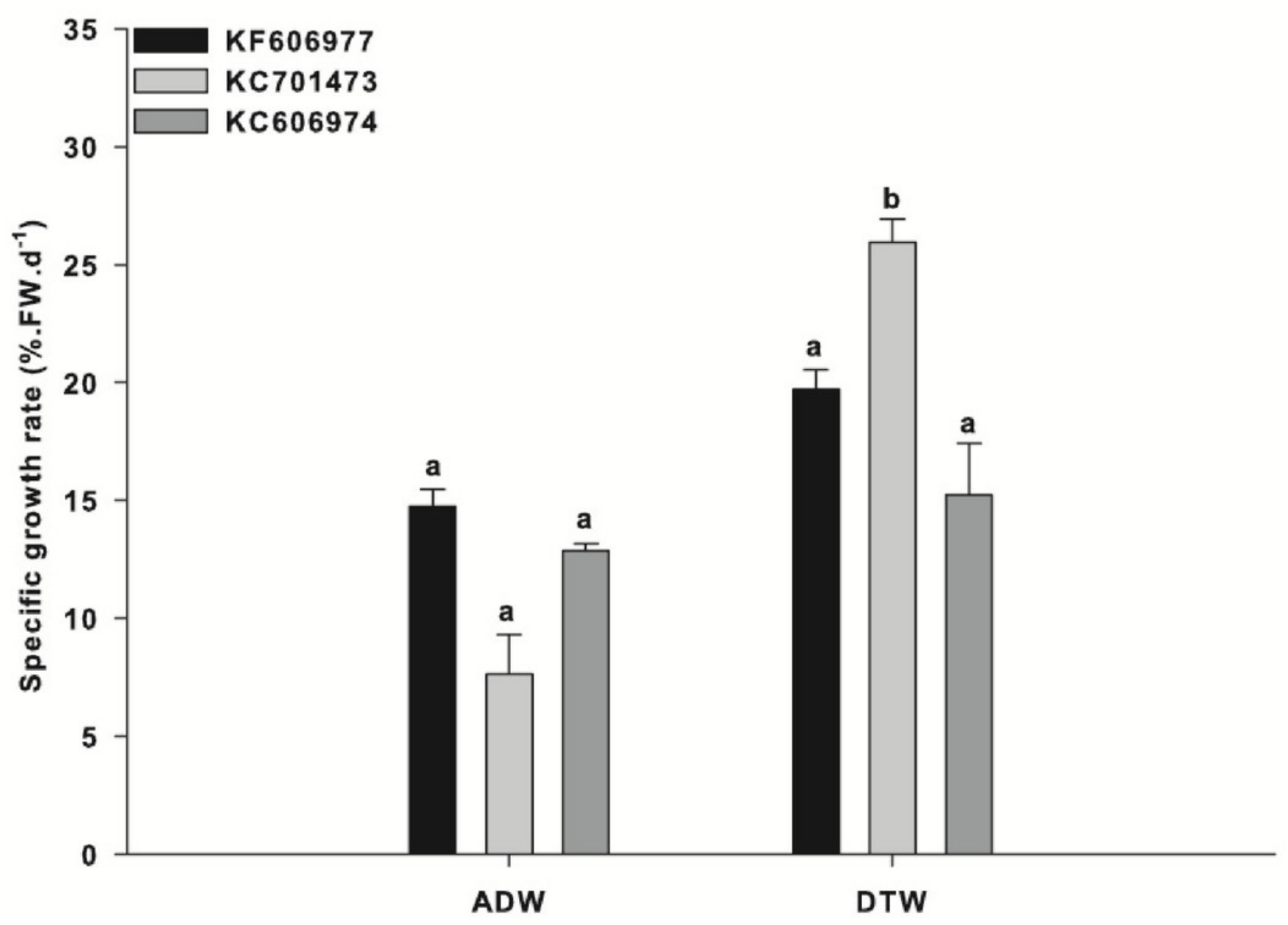




\section{Figure 2}

Figure 2

Mean concentration of a) summed ANZECC metals and b) summed ANZECC metalloids in the three Oedogonium species cultured in Ash Dam Water at time 0 (black bars) and after three weeks of cultivation (grey bars). Data are means \pm SE.
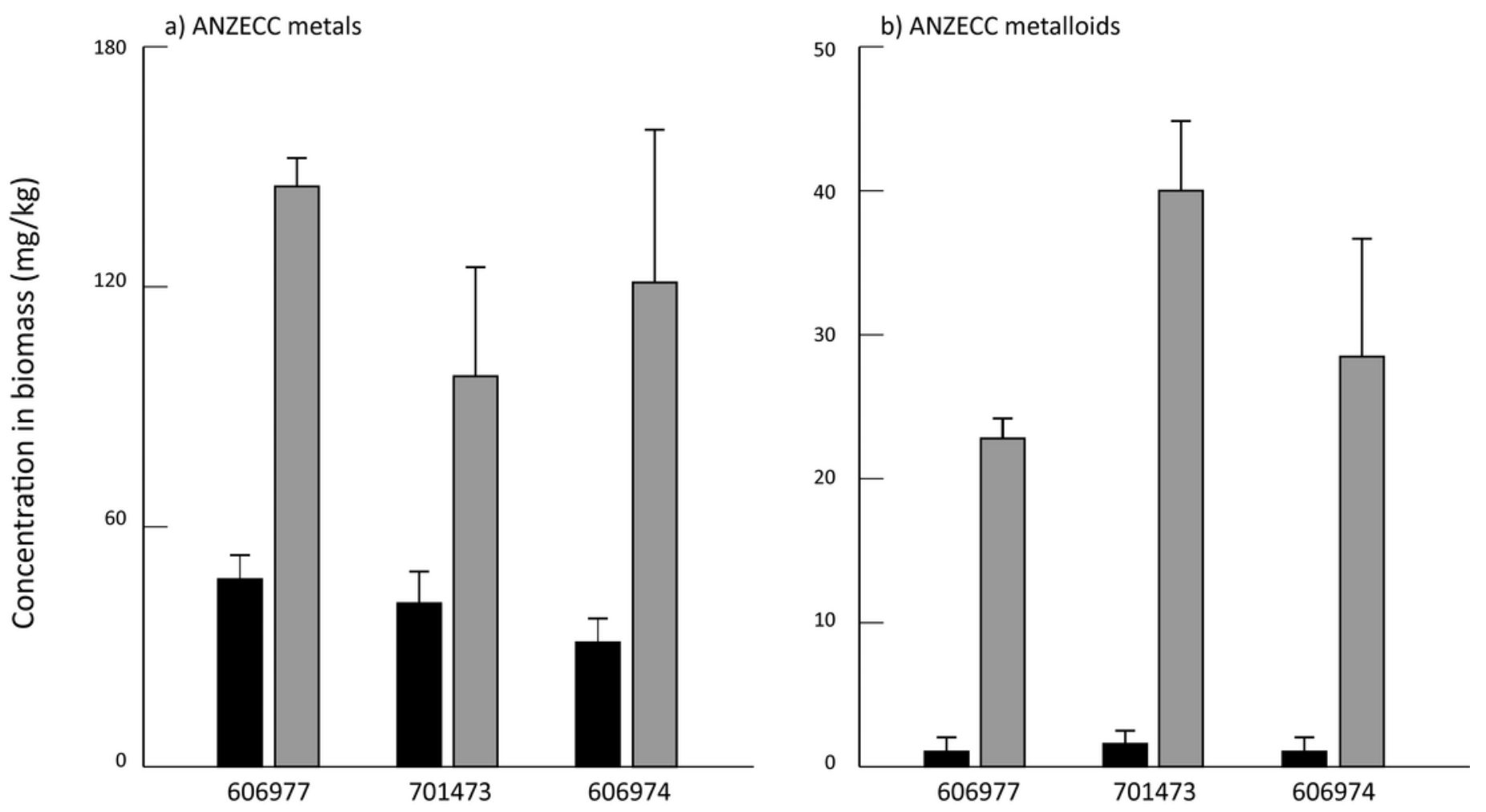


\section{Figure 3}

Figure 3

Mean concentration of metals ( $\mathrm{Al}, \mathrm{Cd}, \mathrm{Ni}$ and $\mathrm{Zn}$ ) and metalloids (As and $\mathrm{Se}$ ) in the three Oedogonium species in Ash Dam Water at time 0 (black bars) and after three weeks of cultivation (grey bars). Data are means \pm SE. 

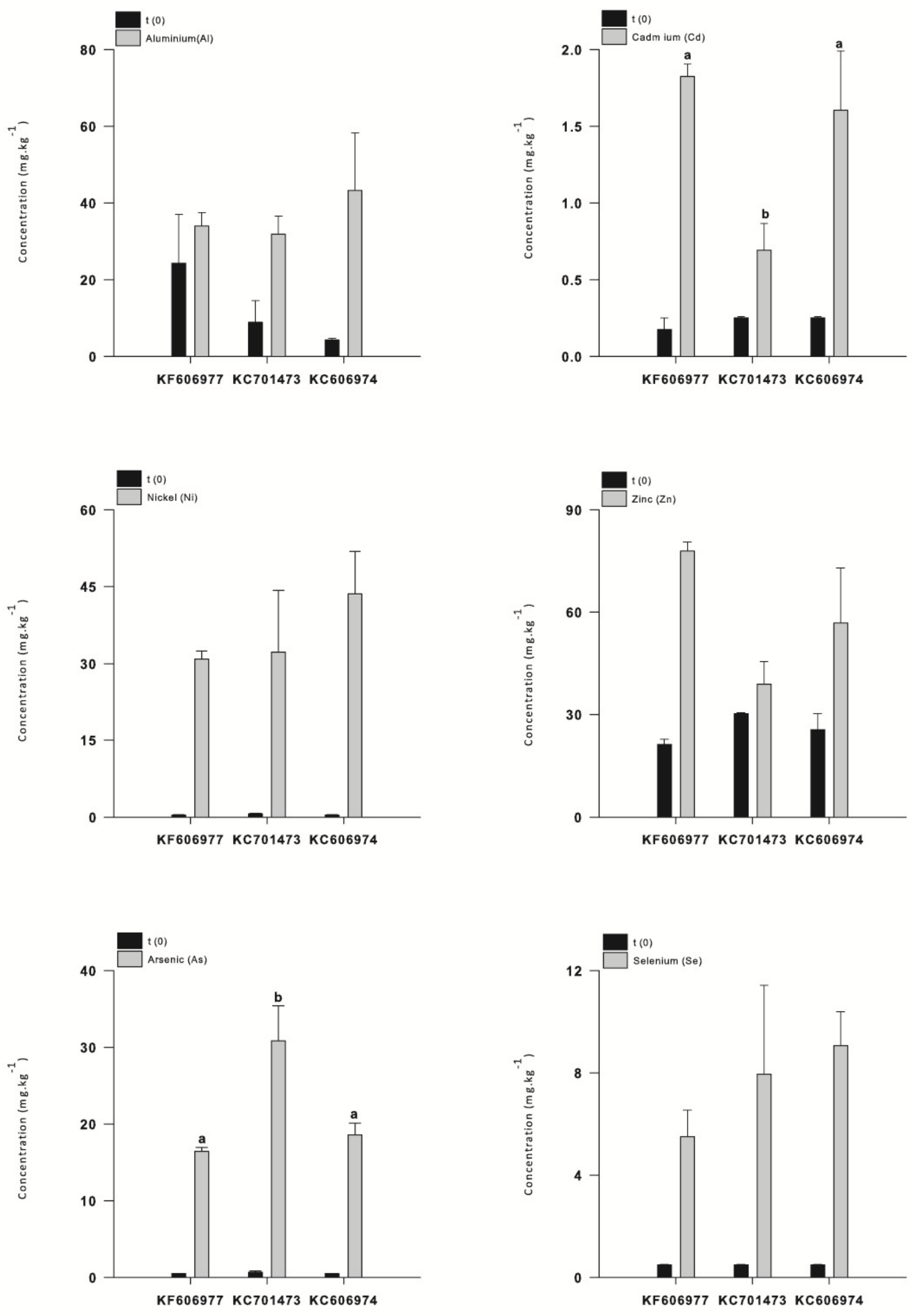


\section{Figure 4}

Figure 4

Nonmetric multidimensional scaling bi-plot of biomass elemental profiles through time.

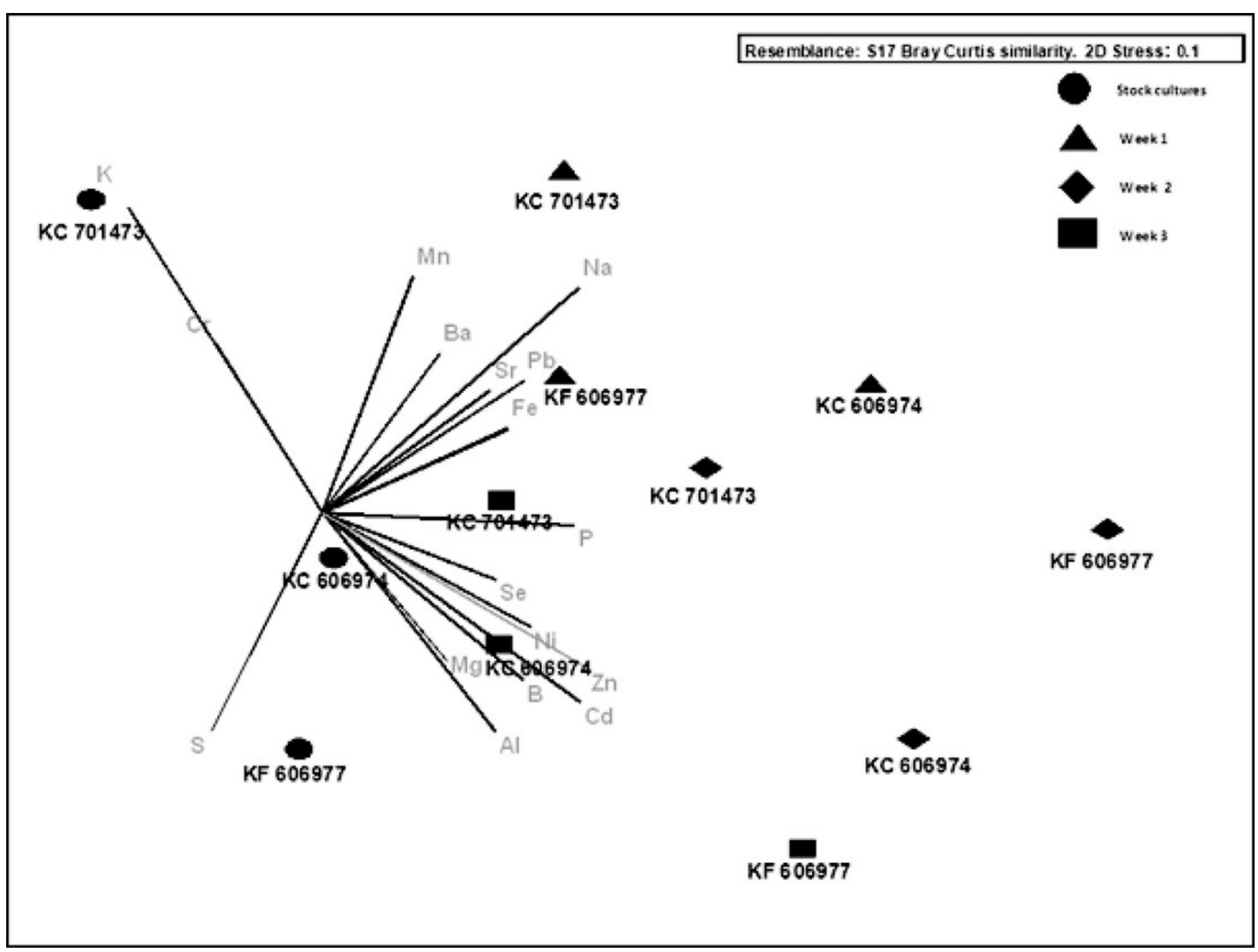




\section{Figure 5}

Figure 5

Bioaccumulation of metals ( $\mathrm{Al}, \mathrm{Cd}, \mathrm{Ni}$ and $\mathrm{Zn}$ ) and metalloids (As and $\mathrm{Se}$ ) by the three Oedogonium species from Ash Dam Water through time. Data are means \pm SE. 

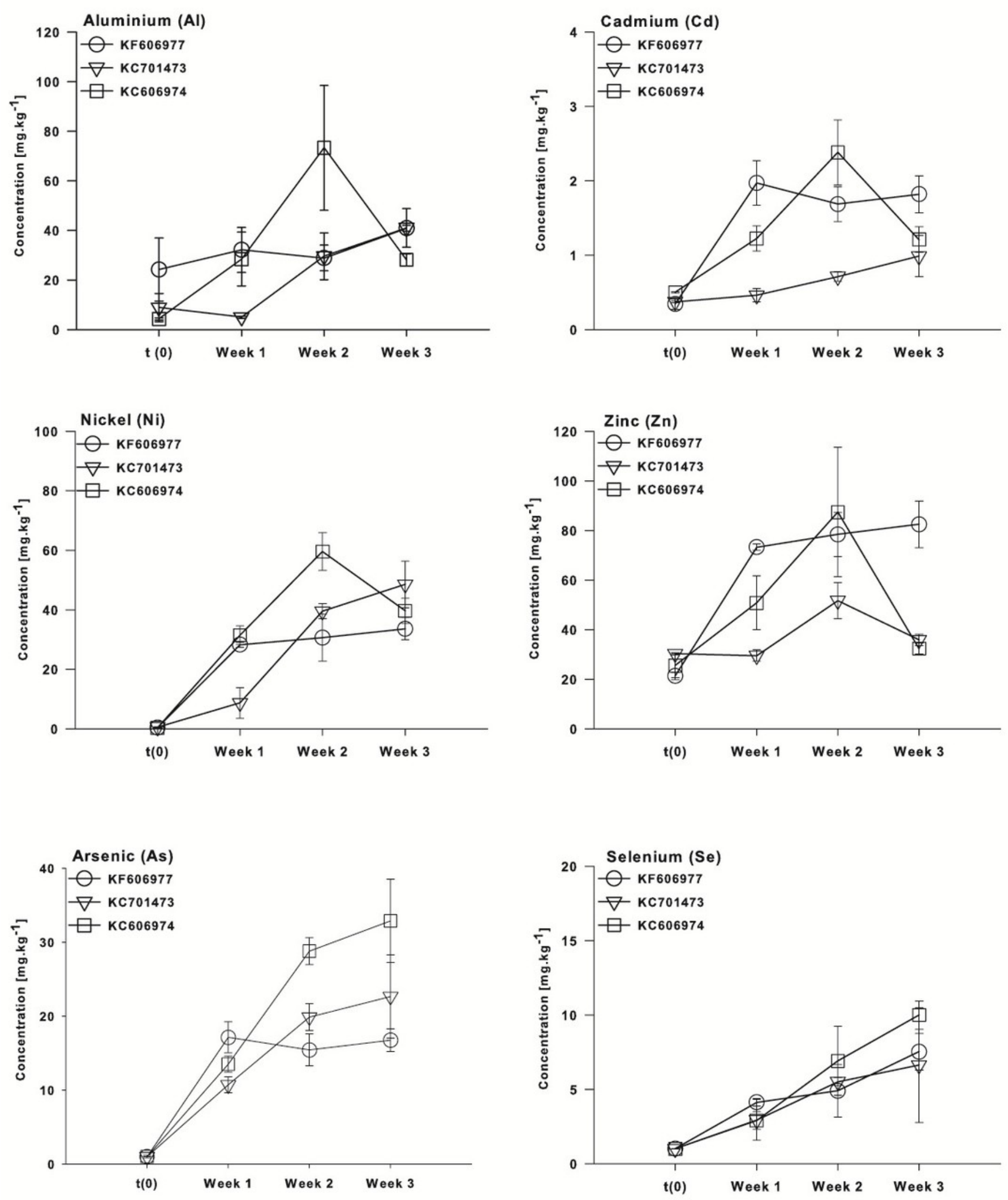